Досліджено фізико-хімічні властивості легуючого сплаву, отриманого відновлювальною плавкою. Це необхідно для визначения параметрів, що знижують втрати Ni та Cr при переробці оксидної легованої сировини та використанні отриманої легуючої добавки. Визначено, що в сплаві при Si:C в иихті 0,14-0,50 (O:C=1,78) присутні фази: твердий розчин $C$ та легуючих елементів в $\gamma$-Fe $\mathrm{ma} \mathrm{Fe}_{3} \mathrm{Si}$. При Si:C=0,14 переважає твердий розчин С та легуючих елементів в $\gamma$-Fе при слабкому прояві Fe3Si. Поетапна зміна Si:C в шихті на 0,26, 0,38 та 0,50 дала підвищення прояву $\mathrm{Fe}_{3} \mathrm{Si}$. Мікроструктура сплаву при різному Si:C в шихті мала чіткий прояв декількох фаз, з різним вмістом основних легуючих елементів. Вміст $\mathrm{Ni}-2,97-14,10 \%$ мас., $\mathrm{Cr}-0,91-$ 17,91\% мас. 3 підвищенням Si:C в иихті з 0,14 до 0,50 спостерігалося підвищення вмісту $\mathrm{Si}_{\text {з }} 0,04 \%$ мас. до 0,55\% мас. Вуглещь в досліджених локальних ділянках поверхні сплаву, що підлягали рентгенівському мікроаналізу, мав значення віӘ 0,51 до 1,48 \% мас. Локальні ділянки мікроструктури з підвищеним Мо (до 9,10\% мас.), Si та С вказують на можливість присутності Мо у вигляді силіцидів або карбосиліцидів. 3 отриманих результатів дослідження витікає, що найбільи прийнятним Si:C в шихті с 0,26 (при О:C=1,78). В ивому випадку забезпечуеться відновлення з переважанням у фазовому складі твердого розчину С та легуючих елементів в $\gamma$-Fе та проявом залишкового Si у вигляді силічидів. Тобто визначено показники отримання сплаву з відносно низьким вмістом Si та C, але достатнім для забезпечення необхідної відновної та розкиснюючої здатності сплаву. Це розширюе можливості ресурсозбереження з використанням отриманого сплаву з заміною деякої частики стандартних легуючих матеріалів при виплавці обмежених по вуглецю та кремнію марок сталей

Ключові слова: окалина корозійностійких сталей, леговані техногенні відходи, відновна плавка, рентгенофазові дослідження

Received date 13.05.2019

Accepted date 27.07.2019

Published date 31.08.2019
UDC $669.15^{\prime} 28-198$

DOI: $10.15587 / 1729-4061.2019 .175914$

\section{STUDY INTO THE STRUCTURAL-PHASE TRANSFORMATIONS ACCOMPANYING THE RESOURCE-SAVING TECHNOLOGY OF METALLURGICAL WASTE PROCESSING}

\author{
A. Petrysh chev \\ $\mathrm{PhD}$, Associate Professor \\ Department of Labour and Environment Protection \\ National University "Zaporizhzhya Polytechnic" \\ Zhukovskoho str., 64, Zaporizhzhya, Ukraine, 69063 \\ E-mail: kafedrales@ukr.net \\ N. Braginec \\ Doctor of Technical Science, Professor \\ Department of Technical Systems and Technologies of Livestock Breeding \\ named after B. P. Shabelnik \\ Kharkiv Petro Vasylenko National Technical University of Agriculture \\ Alchevskykh str., 44, Kharkiv, Ukraine, 61002 \\ V. Borysov \\ Head of Laboratory* \\ V. Bratish ko \\ Doctor of Technical Sciences, Senior Researcher, Associate Professor \\ Department of Livestock Mechanization \\ National University of Life and Environmental Sciences of Ukraine \\ Heroiv Oborony str., 15, Kyiv, Ukraine, 03041 \\ O. Torubara \\ Senior Researcher* \\ B. T s y m b a l \\ $\mathrm{PhD}$ \\ Department of Occupational, Technogenic and Environmental Safety \\ National University of Civil Defence of Ukraine \\ Chernyshevska str., 94, Kharkiv, Ukraine, 61023 \\ S. Borysova \\ Senior Researcher* \\ S. Lu pinovich \\ Senior Researcher* \\ A. Poliakov \\ $\mathrm{PhD}$, Associate Professor \\ Department of Machine Repair, Operation of Energy and Labor Protection \\ Luhansk National Agrarian University \\ Slobozhanska str., 68, Starobelsk, Ukraine, 92703 \\ V. K u z m e n k o \\ $\mathrm{PhD}$, Senior Researcher, Head of Department \\ Department of Biotechnical Systems in Animal Husbandry and Harvesting of Forages \\ National Science Center "Institute of Mechanization and Electrification of Agriculture" \\ Vokzal'na str., 11, smt. Glevaha, Ukraine, 08631 \\ * Research Laboratory of Applied Materials Science \\ Donbass Institute of Technology and Management \\ Mashynobudivnykiv blvd., 32, Kramatorsk, Ukraine, 84313
}

Copyright @ 2019, A. Petryshchev, N. Braginec, V. Borysov, V. Bratishko, O. Torubara, B. Tsymbal, S. Borysova, S. Lupinovich, A. Poliakov, V. Kuzmenko This is an open access article under the CC BY license (http://creativecommons.org/licenses/by/4.0)

\section{Introduction}

Along with modern technologies for obtaining refractory alloying additives based on ore concentrates [1], one of the alternative sources is to recycle alloyed technogenic wastes and return them to production. These include the scale of chromium-nickel containing corrosion-resistant steels. A specific feature of this type of wastes is the dispersity and a relatively high degree of doping. This necessitates taking into consideration the complex nature of physical-chemical 
interaction between elements when developing technological conditions for processing. Thus, the relevance of the current work is predetermined by the current level of using alloying elements, as well as quality, related to the competitiveness of steel articles in the world market.

Therefore, it is a relevant task to save resources and energy while reducing the losses of $\mathrm{Cr}$ and $\mathrm{Ni}$ at processing finely-dispersed wastes from corrosion-resistant steels in metallurgical production. Strategic direction to resolve this issue is to elucidate concepts on the physical-chemical transformations occurring at reduction smelting of oxide waste from the production of corrosion-resistant steels.

\section{Literature review and problem statement}

According to data from paper [2], $\mathrm{Fe}_{3} \mathrm{C}$ and $\mathrm{C}$ were revealed in reduction products following the carbon-based heat treatment of iron scale together with Fe. Similar results were established by authors of work [3] during carbon-based heat reduction of scale from chromium-nickel containing steel. According to the results from phase analysis, the alloying elements were present not in the form of individual compounds but as a solid solution in the Fe phase. That is, the presence of alloying elements in the products from carbon-based heat reduction of scale largely manifests itself by the oxide complex with atoms of iron. This should be considered in the further studies into the reduction and processing of anthropogenic raw materials. However, there is a need to deepen the notions concerning the physical-chemical patterns of interaction between the alloyed anthropogenic raw materials and a reducing agent.

Authors of work [4] reported a study into the reduction reactions involving carbon and oxides in the system $\mathrm{Fe}-\mathrm{Ni}-\mathrm{O}$ at temperatures up to $1,373 \mathrm{~K}$. Increasing the treatment temperature led to the manifestation of reduction products in the following sequence:

$$
\begin{aligned}
& \mathrm{Fe}_{3} \mathrm{O}_{4}+\mathrm{NiO} \rightarrow \mathrm{Fe}_{3} \mathrm{O}_{4}+\mathrm{Ni} \rightarrow \mathrm{FeO}+\mathrm{Fe}_{x} \mathrm{Ni}_{y} \rightarrow \\
& \rightarrow \mathrm{Fe}_{x} \mathrm{Ni}_{y}+\mathrm{Fe}\left(\mathrm{Fe}_{n} \mathrm{C}_{m}\right) .
\end{aligned}
$$

In other words, one observed a relatively higher Ni oxide susceptibility to reduce than that for Fe oxides. At some stages, one observed the formation of metallic Ni and Fe. The authors indicated a possibility of the presence of Fe carbides and the iron-nickel-containing phase $\mathrm{Fe}_{x} \mathrm{Ni}_{y}$, which can also occur when reducing oxide alloyed waste. However, it is impossible to follow the progress of transformations involving a chromium-containing oxide component, which could be present in the scale of corrosion-resistant steels.

Reduction of $\mathrm{FeO} \cdot \mathrm{Cr}_{2} \mathrm{O}_{3}$ oxides at various ratios $\mathrm{C}: \mathrm{Fe}$ and temperatures from $1,373 \mathrm{~K}$ to $1,523 \mathrm{~K}$ was investigated by authors of paper [5]. It was determined that an increase in $\mathrm{C}$ :Fe from 0.8 to 1.4 led to an increase in the degree of removal (\%) of $\mathrm{Cr}$ from 9.6 to 74.3, respectively. Increasing the temperature to $1,523 \mathrm{~K}$ led to an increase in the formation of carbides, whose certain residue is inevitably present in the products reduced by carbon-based heat treatment [6]. At C:Fe below 0.8 , one observed a significant decrease in the degree of extraction of $\mathrm{Cr}$ and a decrease in carbide-formation. The $\mathrm{Cr}$ carbides created diluted in the Fe phase [5]. Formation of $\mathrm{Cr}$ carbides was also discovered by authors of study [7] at reduction of chromic ore. The authors achieved the predefined level of reduction with the formation of $\mathrm{Cr}_{3} \mathrm{C}_{2}$ and $\mathrm{Cr}_{7} \mathrm{C}_{3} \mathrm{Cr}_{3} \mathrm{C}_{2}$ following the carbon-based heat treatment at $1,273 \mathrm{~K}$ and $\mathrm{O}: \mathrm{C}$ within 1.05-1.15. That is, it turns out that achieving an increase in the degree of $\mathrm{Cr}$ extraction at reduction requires that the composition of the charge should contain some excessive carbon relative to oxygen. $\mathrm{Pa}$ pers $[8,9]$ report a study into the reduction of $\mathrm{Cr}_{2} \mathrm{O}_{3}$ by carbon in the range of $1,273-1,773 \mathrm{~K}$. The authors discovered a parallel progress of reduction and formation of carbides $\mathrm{Cr}_{3} \mathrm{C}_{2}, \mathrm{Cr}_{7} \mathrm{C}_{3}, \mathrm{Cr}_{23} \mathrm{C}_{6}$, thereby establishing a possibility to obtain iron-chromate ligatures with a limited carbon content. In other words, it is possible to obtain products reduced by carbon-based heat treatment with relatively low residual carbon, which testifies to the extended scope of application, including alloying corrosion-resistant steels. However, it is impossible to follow patterns in the reduction of a complex of $\mathrm{Cr}$ and $\mathrm{Ni}$ oxides.

Authors of work [10] studied the influence of O:C in the charge on the properties of an alloy obtained from the waste of chromium-nickel-containing corrosion-resistant steels. They noted that the most acceptable O:C in the charge is 1.78 , which should be considered in research when choosing technological parameters. The predominance in the phase composition of a solid solution of $\mathrm{C}$ and alloying elements in -Fe was provided with a relatively weak manifestation of residual carbon in the form of a carbide component. However, they did not investigate the impact of adding a silicon reducing agent to the charge on the phase composition and structure of the alloy.

Authors of paper [11] investigated phase-formation in the system $\mathrm{Fe}-\mathrm{Ni}-\mathrm{Si}$. It was found that phases of $\mathrm{FeSi}$ and $\mathrm{Fe}_{3} \mathrm{Si}$ have relatively high values of solubility for $\mathrm{Ni}$, inn contrast to the phase of $\mathrm{FeSi}_{2}$. The formation of $\mathrm{Fe}_{3} \mathrm{Si}$ silicide was revealed in the system $\mathrm{Fe}-\mathrm{Cr}-\mathrm{C}-\mathrm{Si}$ by authors of work [12] in an applied coating from the alloy of brand 45Fe39Cr6C10Si. Results from papers [11, 12] indicate that the reduction of oxide waste from corrosion-resistant steels using $\mathrm{Si}$ could be accompanied by the formation of iron silicides with the dissolved alloying elements. However, it is impossible, using sources [11,12], to trace the features in the phase composition of products reduced at a different content of $\mathrm{C}$ and $\mathrm{Si}$ in the studied systems.

Authors of work [13] confirmed experimentally the existence in the system $\mathrm{Ni}-\mathrm{Cr}-\mathrm{Si}$ at $1,273 \mathrm{~K}$ and $1,373 \mathrm{~K}$ of ternary compounds $\mathrm{Cr}_{13} \mathrm{Ni}_{5} \mathrm{Si}_{2}, \mathrm{Cr}_{3} \mathrm{Ni}_{5} \mathrm{Si}_{2}, \mathrm{Cr}_{2} \mathrm{Ni}_{2} \mathrm{Si}$ and $\mathrm{Cr}_{3} \mathrm{Ni}_{3} \mathrm{Si}_{4}$. Binary phases $\mathrm{Ni}_{31} \mathrm{Si}_{12}, \mathrm{Ni}_{2} \mathrm{Si}$ and $\mathrm{CrSi}$ showed significant solubility of a third element. Authors of paper [14] studied experimentally the reduction of chromic ore by particles of $\mathrm{Si}$ and $\mathrm{SiC}$ in the temperature range from $1,389-1,661 \mathrm{~K}$. the revealed the formation of metal particles with components of $\mathrm{Fe}, \mathrm{Cr}$ and $\mathrm{Si}$ and established that temperatures above $1,473 \mathrm{~K}$ are required to reduce chromic ore. Article [15] describes a pattern of increasing the degree of reduction of $\mathrm{Cr}$ from ore raw materials in the temperature interval of $1,573-2,473 \mathrm{~K}$ from $42.7 \%$ to $95.1 \%$. This is achieved by increasing the content of a reducing agent (ferrosilico nickel containing, $\%$ by weight, $\mathrm{Fe}-28, \mathrm{Si}-65 ; \mathrm{Ni}-7$ ) from $50 \%$ to $105 \%$ of the required stochiometric amount. That is, when reducing the scale of corrosion-resistant steels, one should not rule out a possibility of interaction between the alloying elements and $\mathrm{Si}$ and the formation of complex triple and double compounds. A relatively high reduction of chromium-containing component of scale from corrosion-resistant steel can be ensured through the intensification of a thermal regime and some excessive reducing agent in terms 
of stoichiometry. However, it is not possible to follow the sequence of changes in the phase composition and structure of reduction products when regulating the content of $\mathrm{Si}$ in the starting products.

One should note very important results from studying scale reduction by carbon-based heat treatment of carbon [2] and alloyed steels [3]. Also significant are the results from paper [10] reporting a study into the influence of O:C in the charge on the physical-chemical properties of reduction products. However, there is not enough information about the interaction between scale and $\mathrm{Si}$ as a reducing agent. Research into oxides exposed to carbon-based heat treatment in the systems $\mathrm{Fe}-\mathrm{Ni}-\mathrm{O}-\mathrm{C}$ [4] and $\mathrm{Fe}-\mathrm{Cr}-\mathrm{O}-\mathrm{C}$ [5] deepen the knowledge on the reduction of oxide waste from corrosion-resistant steels. In this case, results from [7] are rather important, which confirm the processes of $\mathrm{Cr}_{3} \mathrm{C}_{2}$ and $\mathrm{Cr}_{7} \mathrm{C}_{3}$ formation. Along with this, $\mathrm{Cr}_{23} \mathrm{C}_{6}$ may form [8] providing an opportunity to obtain iron-chromate ligatures with a limited carbon content [9]. However, the issue related to the influence of reducing factors on the phase and structural component of targeted products was not studied in detail. Significant results from studying the existence of phases in systems $\mathrm{Fe}-\mathrm{Ni}-\mathrm{Si}$ are given in [11], $\mathrm{Fe}-\mathrm{Cr}-\mathrm{C}-\mathrm{Si}-$ in [12], and in system $\mathrm{Ni}-\mathrm{Cr}-\mathrm{Si}-$ in [13]. Also significant are the results from a study into the progress of restoration in systems $\mathrm{Cr}-\mathrm{Fe}-\mathrm{O}-\mathrm{C}-\mathrm{Si}[14]$ and $\mathrm{Ni}-\mathrm{Cr}-\mathrm{Fe}-\mathrm{O}-\mathrm{C}-$ $\mathrm{Si}$ [15]. However, the authors did not show the influence of change in $\mathrm{Si}: \mathrm{C}$ in the charge on the phase composition and microstructure of reduction products. Research into this field could reduce the loss of $\mathrm{Cr}$ and Ni through the sublimation of oxide compounds when obtaining and utilizing a reduced doped material.

Therefore, it is a relevant task to study regularities in the influence of parameters of ratio Si to $\mathrm{C}$ in the charge on the phase composition and microstructure of a resource-saving doped alloy obtained from reduction smelting. That would make it possible to define the character of the presence of elements in the alloy. Along with this, using $\mathrm{x}$-ray microanalysis of individual inclusions and phases could provide for a better understanding of the distribution of alloying elements in the resulting alloy.

\section{The aim and objectives of the study}

The aim of this study was to investigate the physical and chemical features of chromium-nickel-containing waste from production of corrosion-resistant steels and doped alloy, obtained by means of reduction smelting. That is required to identify the parameters that reduce the losses of $\mathrm{Ni}$ and $\mathrm{Cr}$ by sublimation at processing oxide alloying raw materials and by using the obtained doping additive.

To achieve the set aim, the following tasks have been solved:

- to identify features of the phase composition of a doped alloy based on the technogenic waste from corrosion-resistant steels with a different ratio of $\mathrm{Si} \mathrm{C}$ in the charge in terms of the character of the presence of elements;

- to explore the microstructure and chemical composition of individual phases and inclusions in a resource-saving chromium-nickel-containing doped alloy with a varying ratio of $\mathrm{Si}: \mathrm{C}$ in the charge.
4. Materials and methods to study properties of technogenic raw materials and the resulting alloy

41. Examined materials and equipment used in the experiment

The original raw materials - a mixture of scale from chromium-nickel-containing corrosion-resistant steels, type $18-10$, formed at the process stage of metallurgical production. A reducing agent is carbon, in the form of ultrafine dust from carbon-graphite production (the proportion of carbon is $98 \%$ by weight), adding which provided for a ratio of $\mathrm{O}: \mathrm{C}$ in the charge at the level of 1.78. A change in the amount of silicon in the alloy was enabled by adding ferrosilicium to the charge, brand FS-65, by adjusting the ratio of $\mathrm{Si}: \mathrm{C}$ in the charge within $0.14-0.50$. To intensify the heating of charge and the reduction processes, we added chips from grinding the steel 08H17N5M3. Samples for our study were melted at an indirect heating furnace with a coal lining in alundian crucibles. The temperature of smelting was 1,873-1,913 K. Upon smelting, the alundian crucibles, together with the alloy, were taken out of the furnace and cooled at a temperature of ambient air.

X-ray phase analysis of the samples was carried out at the diffractometer "DRON-6" (Russia).

Photographs of the microstructure and chemical composition of individual sections at the surface of the samples were acquired from the raster electron microscope JSM 6360LA, equipped with the system of $\mathrm{x}$-ray microanalysis JED 2200, manufactured by JEOL (Japan).

\section{2. Procedure for experiments and for determining} indicators of the samples' properties

The phase composition of samples was determined by the method of X-ray phase analysis using the monochromatic radiation of $\mathrm{Cu} \mathrm{K}_{\alpha}(\lambda=1.54051 \AA)$ from $\mathrm{Ni}$ applying a filter. Measurements were performed at a voltage on the tube of $U=40 \mathrm{kV}$ and at anode current $I=20 \mathrm{~mA}$. The composition of phases was determined employing the software package PDWin 2.0 (Russia).

We studied the microstructure of samples at an accelerating voltage of $15 \mathrm{kV}$ and at a diameter of the electronic probe of $4 \mathrm{~nm}$. The phase composition was determined using a reference-free method of basic parameters calculation.

\section{Results from studying the properties of the original} technogenic raw materials and the resulting doped alloy

5. 1. Determining the features of the phase composition of the alloy with different $\mathrm{Si}: \mathrm{C}$ in the charge

Phase composition of the alloy with $\mathrm{Si}$ : $\mathrm{C}$ in the charge of 0.14 consisted mainly of a solid solution of $\mathrm{C}$ and the alloying elements in $\gamma$ - $\mathrm{Fe}$ with the manifestation of $\mathrm{Fe}_{3} \mathrm{Si}$ at relatively low intensity (Fig. 1,a). At $\mathrm{Si}$ : C in the charge of 0.26 , we observed a slight increase in the manifestation of $\mathrm{Fe}_{3} \mathrm{Si}$ relative to the solid solution of $\mathrm{C}$ and the alloying elements in $\gamma$-Fe. The ratio of Si:C in the charge of 0.38 and 0.50 led to a decrease in the manifestation of a solid solution of $\mathrm{C}$ and the alloying elements in $\gamma$-Fe and an increase in the intensity of diffraction maxima for $\mathrm{Fe}_{3} \mathrm{Si}$. $\mathrm{Fe}_{3} \mathrm{C}$ carbide manifested itself across the entire examined range of $\mathrm{Si} \mathrm{C}$ in a fragmented fashion with a relatively low intensity of diffraction maxima, which approached the level of the background. 
The microstructure of the examined alloy consisted of several phases (Fig. $1, b-d$ ) with a different shape and size of the particles. We have detected phases with a relatively high content of $\mathrm{Cr}$, up to $17.91 \% \%$ by weight (Fig. 1, 2, Table 1) and $\mathrm{Ni}$, to $14.2 \% \%$ by weight. The examined areas of the composition of samples 6 and 10 contained a higher content of Mo, $4.49 \%$ \% by weight and $9.10 \%$ by weight, respectively. Si and $\mathrm{C}$ in the specified areas also demonstrated relatively high levels in terms of weight content. Increasing $\mathrm{Si}: \mathrm{C}$ in the charge from 0.14 to 0.50 led to an increase in the content of $\mathrm{Si}$ in the examined areas of the alloy, from $0.04 \%$ by weight to $0.55 \%$ by weight. Carbon in the examined local areas of the surface of the alloy exposed to X-ray microanalysis accepted values from 0.51 to $1.48 \%$ by weight, given in Table 1.

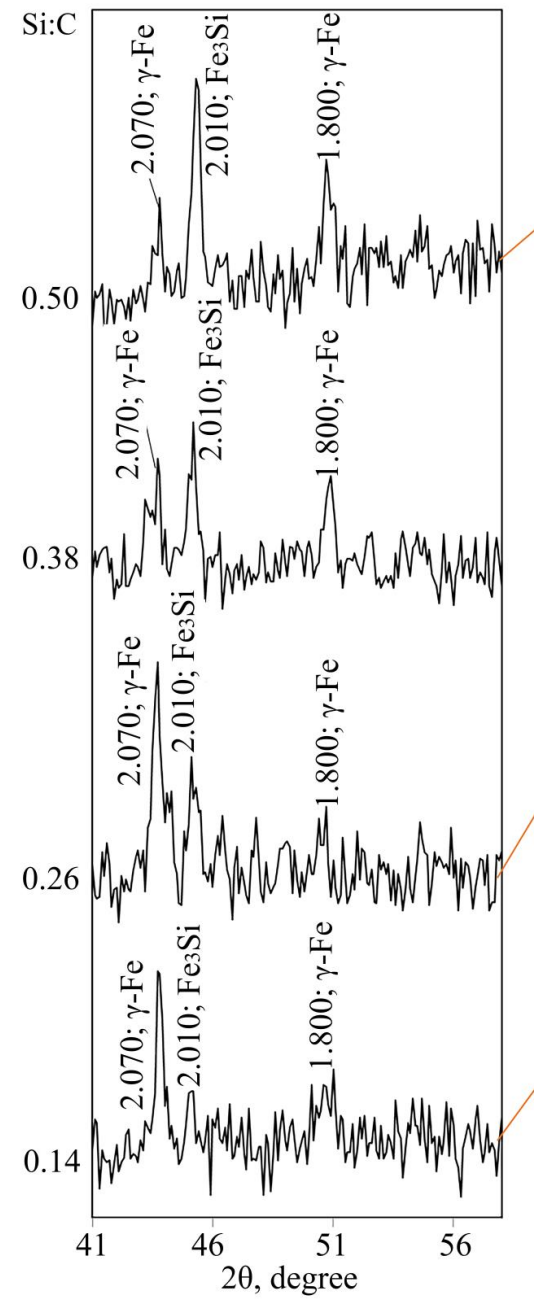

a
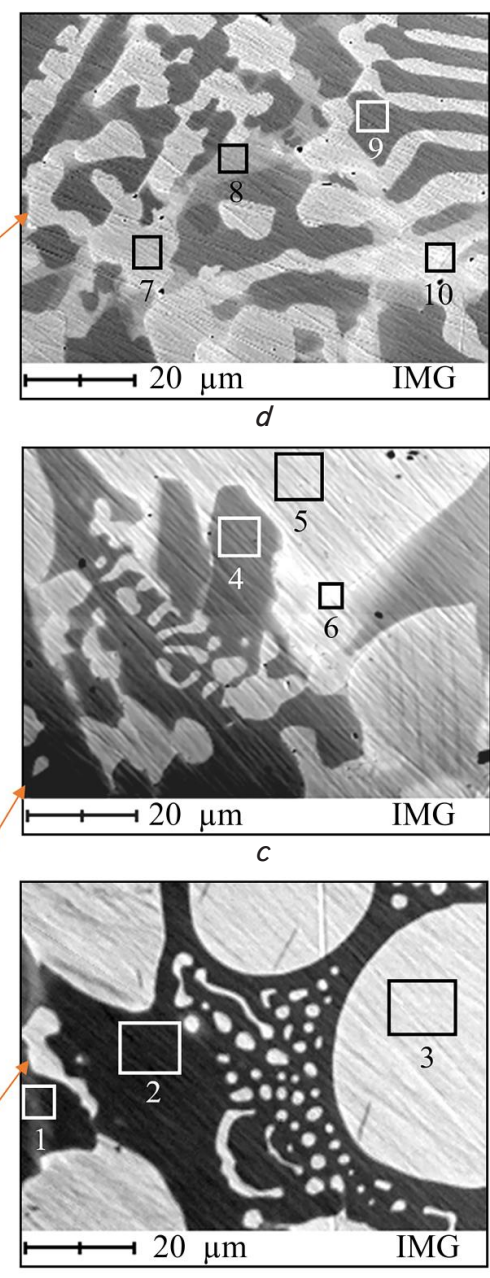

$b$
Fig. 1. X-ray phase study of the doped alloy with a varying ratio of $\mathrm{Si}: \mathrm{C}$ in the charge at $\mathrm{O}: \mathrm{C}=1.78$ and the respective photographs of the microstructure at magnification $\times 1,500$ : $a$ - sections of diffractograms; $b-0.14, c-0.26$,

$d-0.50,1-10-$ sections of X-ray microanalysis of the samples

The derived microsections clearly demonstrated the manifestation of several phases (Fig. 1, $b$ ). At C:Si in the charge of 0.14 the microsection exhibits phase formations of rounded shape. Such a phase was dominated by the content of $\mathrm{Ni}(14.10 \%$ by weight) with respect to $\mathrm{Cr}(0.91 \%$ by weight), see Table 1, section 3 . A similar pattern was observed with a gradual increase in $\mathrm{C}: \mathrm{Si}$ in the charge to 0.26 and 0.50 (Fig. 1, $d$ ). In this case, the sections of the specified phase acquired a non-regular shape, some inclusions were more elongated. The phase was dominated by $\mathrm{Ni}$ relative to entire section of the examined $\mathrm{C}: \mathrm{Si}$ the charge exhibited a phase with a larger content of $\mathrm{Cr}$ (Table 1 , sections 1, 2, 4, 9). alloying elements in $\gamma$-Fe. A silicide component probably had ocal character. The examined section 10, Table 1, indicates tent of C (1.23\% by weight), Si ( $0.55 \%$ by weight) and Mo carbide, silicide, or carbosilicide phases.
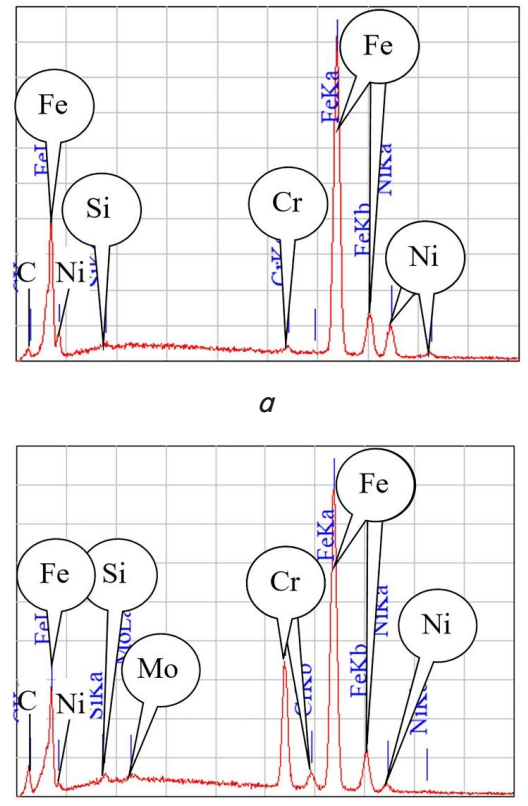

$b$

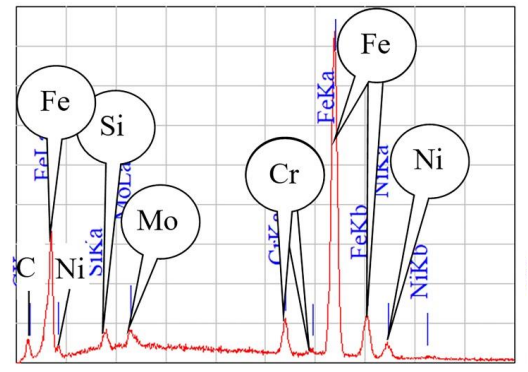

C

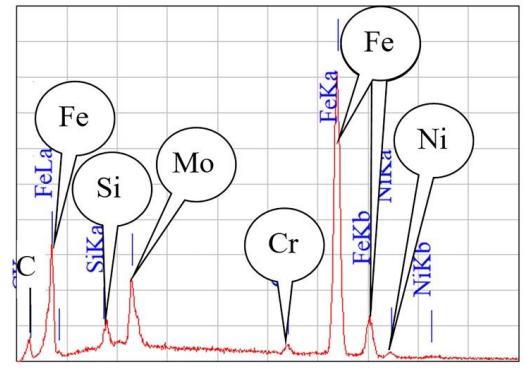

d

Fig. 2. Spectrograms of some examined sections of X-ray microanalysis of samples in accordance with Fig. 1:

$a-3, b-4, c-8, d-10$ 
Table 1 There is also agreement with the research reported in [11],

Results from X-ray microanalysis of the doped alloy in accordance with Fig. 1

\begin{tabular}{|c|c|c|c|c|c|c|c|c|}
\hline \multirow{2}{*}{\multicolumn{2}{|c|}{\begin{tabular}{|c|} 
Sections to \\
examine the \\
samples' compo- \\
sition \\
\end{tabular}}} & \multicolumn{7}{|c|}{ Content of elements, \% by weight } \\
\hline & & $\mathrm{C}$ & $\mathrm{Si}$ & $\mathrm{Cr}$ & $\mathrm{Fe}$ & $\mathrm{Ni}$ & Mo & $\begin{array}{c}\text { Total } \\
\text { content }\end{array}$ \\
\hline 1 & \multirow{2}{*}{$\begin{array}{c}\text { Averaged } \\
\text { value }\end{array}$} & \multirow{2}{*}{1.09} & \multirow{2}{*}{0.04} & \multirow{2}{*}{8.73} & \multirow{2}{*}{85.83} & \multirow{2}{*}{3.91} & \multirow{2}{*}{0,40} & \multirow{2}{*}{100} \\
\hline 2 & & & & & & & & \\
\hline & 3 & 0,51 & 0.06 & 0.91 & 84.42 & 14.10 & 0.00 & 100 \\
\hline & 4 & 1,48 & 0.16 & 17.91 & 77.06 & 2.97 & 0.42 & 100 \\
\hline 5 & \multirow{2}{*}{$\begin{array}{c}\text { Averaged } \\
\text { value }\end{array}$} & \multirow{2}{*}{1.15} & \multirow{2}{*}{0.21} & \multirow{2}{*}{1.84} & \multirow{2}{*}{83.55} & \multirow{2}{*}{11.00} & \multirow{2}{*}{2,25} & \multirow{2}{*}{100} \\
\hline 6 & & & & & & & & \\
\hline & 7 & 1,05 & 0.34 & 1.65 & 86.21 & 9.96 & 0.79 & 100 \\
\hline & 8 & 1,06 & 0.31 & 4.74 & 87.08 & 5.90 & 0.91 & 100 \\
\hline & 9 & 1,29 & 0.30 & 6.34 & 86.11 & 5.48 & 0.48 & 100 \\
\hline & 10 & 1,23 & 0.55 & 1.21 & 85.64 & 2.27 & 9.10 & 100 \\
\hline
\end{tabular}

Determining the concentration of elements in the examined section of the sample's surface (Fig. 3) indicates a clear division between phases with a higher content of $\mathrm{Cr}$ and $\mathrm{Ni}$.

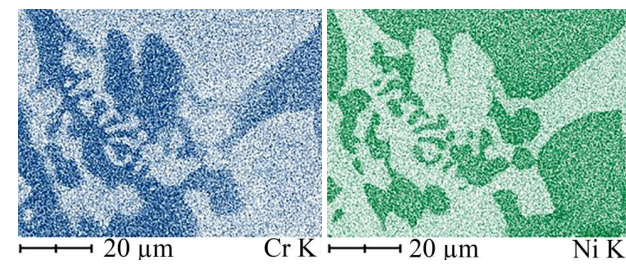

a

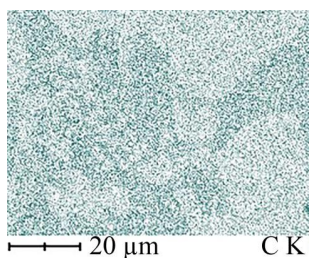

d

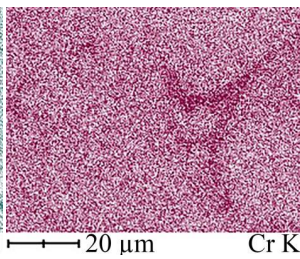

e

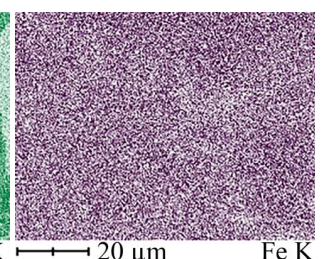

$c$

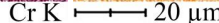

$f$
Fig. 3. Results from X-ray microanalysis under the mode of distribution of elements in the characteristic $\mathrm{X}$-ray beams according to Fig. 1, $c$, (magnification $\times 1,500$ ). The greater content of the element is matched with a more intense coloration: $a-\mathrm{Cr}, b-\mathrm{Ni}, c-\mathrm{Fe}, d-\mathrm{C}, e-\mathrm{Si}, f-\mathrm{Mo}$

The content of Fe is relatively uniform throughout the entire examined section, and carbon manifested itself in a more intensive fashion in the phase with a higher concentration of $\mathrm{Cr}$. We have discovered a local section with a relatively high content of Si and Mo (Fig. 3, e,f).

\section{Discussion of results from studying the properties of technogenic raw materials and the resulting doped alloy}

Phase analysis of the alloy with varying Si:C in the charge (Fig. 1) indicates that the alloying elements and carbon were in a solid solution in the lattice $\gamma$-Fe. Some part of the alloying elements can act as the substitution atoms in the compound $\mathrm{Fe}_{3} \mathrm{Si}$. This agrees well with results from paper [12], whose authors revealed, in the examined system $\mathrm{Fe}-\mathrm{Cr}-\mathrm{C}-\mathrm{Si}$, the formation of the respective iron silicide. which argued about a relatively high solubility of $\mathrm{Ni}$ in the phase $\mathrm{Fe}_{3} \mathrm{Si}$. Along with this, it corresponds to the results described in [3], in which a diffractogram of the reduced doped product clearly demonstrated the manifestation of iron-containing compounds only.

The presence of atoms of the alloying elements as a solid solution together with carbon in the lattice $\gamma$-Fe and silicides $\mathrm{Fe}_{3} \mathrm{Si}$ is indicated by the results from studying the microstructure, and X-ray microanalysis (Fig. 1, 2, Table 1). One can see that some examined areas were characterized by a relatively high content of $\mathrm{Cr}$ and carbon (Table 1). That could probably be attributed to the local presence of iron-chromium-containing carbides. This is consistent with the results from papers [7-9], which indicated the progress of chromium-containing carbides formation in parallel with reduction. Also confirmed is the impossibility to obtain a totally carbon-free product, which agrees well with the results reported in $[2,6]$. We do not rule out the possibility of dissolving some part of the locally formed carbides in the solid solution of $\gamma$-Fe in a contact between two phases, which is also noted by authors of paper [5].

The phase with a relatively high content of $\mathrm{Ni}$, discovered on the photographs of the microstructure (Table 1 , sections $3,5,7$ ), is probably a solid solution of carbon and the alloying elements in $\gamma$-Fe. This is consistent with study [4], which confirmed the efficiency of reduction of an iron-nickel component by carbon, and with paper [10], whose authors obtained, following the reduction smelting, a similar distribution of elements between phases.

The photographs of distribution of the alloying elements (Fig. 3) show that Mo is probably to a greater extent present locally in the form of silicides, carbides, or carbosilicides. This is evidenced by the more intense coloration of individual sections (Fig. 3, $d-f$ ) in accordance with the X-ray microanalysis for determining chemical composition (Fig. 1,c, Table 1, section 6).

The obtained samples lack the compounds and phases with a relatively high susceptibility to sublimation. In other words, there is no need to create special conditions that would prevent the evaporation and loss of alloying elements along with a gaseous phase. This also predetermines an increase in the degree of using alloying elements.

It follows from the results of our study that the most acceptable Si:C in the charge is 0.26 . This ensures the reduction with a predominance, in the phase composition, of the solid solution of $\mathrm{C}$ and the alloying elements in -Fe and the manifestation of residual $\mathrm{Si}$ in the form of a silicide component. In other words, we have defined indicators for obtaining a product from reduction smelting with a relatively low content of $\mathrm{Si}$, and $\mathrm{C}$, which is sufficient to provide for the required reducing and oxidizing capability. That extends the possibilities to use the resulting alloy with the replacement of some part of standard alloying materials when smelting the grades of steels with limitations in the composition for silicon and carbon.

A drawback that should be noted is the lack of photographs of the sections of the microstructure of samples at different magnification, which could have improved the visualization of the current study. 
Our research could be advanced in the field of extending the range of grades of steel whose oxide wastes could be involved in processing by the reduction melting technique. The most promising wastes are those with an elevated level of doping.

The arc furnace DSV-40 with a basic lining was used to perform experimental- industrial smelting of corrosion-resistant steel, type 18-10. The doping additive used was an alloy based on industrial waste. The doping alloy was used as a partial replacement for standard alloying materials, as the charge with a consumption of $270-330 \mathrm{~kg} / \mathrm{t}$ of steel. The chemical composition of the alloy, \% by weight, is $\mathrm{C}-$ 0.03-0.05, $\mathrm{Si}-0.50-1.80, \mathrm{Mn}-0.5-2.0, \mathrm{Cr}-15.0-25.0$, $\mathrm{Ni}-8.0-14.0, \mathrm{Ti}-0.50-1.20, \mathrm{Al}-0.50-1.80, \mathrm{Cu} \leq 0.50$, $\mathrm{S} \leq 0.025, \mathrm{P} \leq 0.035, \mathrm{Fe}-$ remaining. The burn-out of the alloying elements fell by $3-4 \%$ by weight. In this case, we achieved a decrease in the consumption of $\mathrm{Ni}$ and $\mathrm{Cr}$ by $27-31 \%$ by weight and by $25-29 \%$ by weight, respectively, when using the doped alloy [10].

\section{Conclusions}

1. It was determined that the alloy at $\mathrm{Si}: \mathrm{C}$ in the charge within $0.14-0.50(\mathrm{O}: \mathrm{C}=1.78)$ includes the following phases: a solid solution of $\mathrm{C}$ in $\gamma$ - $\mathrm{Fe}$ and $\mathrm{Fe}_{3} \mathrm{Si}$ with the alloying elements as the substitution atoms. At $\mathrm{Si}: \mathrm{C}=0.14$, the phase composition mostly consisted of the solid solution of $\mathrm{C}$ and the alloying elements in $\gamma$-Fe with a weakly manifested $\mathrm{Fe}_{3} \mathrm{Si}$. A stepwise change in Si:C in the charge to 0.26, 0.38, 0.50 led to the increased manifestation of $\mathrm{Fe}_{3} \mathrm{Si}$. The $\mathrm{Fe}_{3} \mathrm{C}$ carbide manifested itself, across the entire examined range of $\mathrm{Si} C \mathrm{C}$, in a fragmented fashion, with a relatively low intensity of diffraction maxima, which approached the level of the background.

2. It was determined that the microstructure of the doped alloy with varying $\mathrm{Si} C \mathrm{C}$ in the charge clearly demonstrated the manifestation of several phases, which were characterized by a difference in the content of basic alloying elements. The content of $\mathrm{Ni}$ in the examined local sections of different phases varied within $2.97-14.10 \%$ by weight, $\mathrm{Cr}-0.91-17.91 \%$ by weight. An increase in Si:C in the charge from 0.14 to 0.50 led to the observed increase in the content of $\mathrm{Si}$ in the examined sections of alloy, from $0.04 \%$ by weight to $0.55 \%$ by weight. Carbon in the examined local sections of the alloy's surface exposed to X-ray microanalysis accepted values from 0.51 to $1.48 \%$ by weight. The presence of Mo was within up to $9.10 \%$ by weight. Local sections of the microstructure with elevated $\mathrm{Mo}, \mathrm{Si}$, and $\mathrm{C}$ indicate a possibility of the presence of Mo in the form of silicides, carbides, or carbosilicides.

\section{References}

1. Grigor'ev, S. M., Petrishchev, A. S. (2015). Refining metallized molybdenum concentrate by means of a low-temperature plasma-forming mixture. Steel in Translation, 45 (12), 954-958. doi: https://doi.org/10.3103/s0967091215120049

2. Mechachti, S., Benchiheub, O., Serrai, S., Shalabi, M. (2013). Preparation of iron Powders by Reduction of Rolling Mill Scale. International Journal of Scientific \& Engineering Research, 4 (5), 1467-1472.

3. Hryhoriev, S., Petryshchev, A., Shyshkanova, G., Zaytseva, T., Frydman, O., Krupey, K. et. al. (2018). A study of environmentally friendly recycling of technogenic chromium and nickel containing waste by the method of solid phase extraction. Eastern-European Journal of Enterprise Technologies, 1 (10 (91)), 44-49. doi: https://doi.org/10.15587/1729-4061.2018.121615

4. Zhang, Y., Wei, W., Yang, X., Wei, F. (2013). Reduction of Fe and Ni in Fe-Ni-O systems. Journal of Mining and Metallurgy, Section B: Metallurgy, 49 (1), 13-20. doi: https://doi.org/10.2298/jmmb120208038z

5. Zhao, L., Wang, L., Chen, D., Zhao, H., Liu, Y., Qi, T. (2015). Behaviors of vanadium and chromium in coal-based direct reduction of high-chromium vanadium-bearing titanomagnetite concentrates followed by magnetic separation. Transactions of Nonferrous Metals Society of China, 25 (4), 1325-1333. doi: https://doi.org/10.1016/s1003-6326(15)63731-1

6. Ryabchikov, I. V., Belov, B. F., Mizin, V. G. (2014). Reactions of metal oxides with carbon. Steel in Translation, 44 (5), 368-373. doi: https://doi.org/10.3103/s0967091214050118

7. Hryhoriev, S., Petryshchev, A., Shyshkanova, G., Yakimtsov, Y., Zhuravel, S., Yamshinskij, M. et. al. (2017). Study into properties of the resourcesaving chromiumcontaining briquetted alloying additive from ore raw materials. Eastern-European Journal of Enterprise Technologies, 4 (12 (88)), 38-43. doi: https://doi.org/10.15587/1729-4061.2017.108191

8. Simonov, V. K., Grishin, A. M. (2013). Thermodynamic analysis and the mechanism of the solid-phase reduction of $\mathrm{Cr}_{2} \mathrm{O}_{3}$ with carbon: Part 1. Russian Metallurgy (Metally), 2013 (6), 425-429. doi: https://doi.org/10.1134/s0036029513060153

9. Simonov, V. K., Grishin, A. M. (2013). Thermodynamic analysis and the mechanism of the solid-phase reduction of $\mathrm{Cr}_{2} \mathrm{O}_{3}$ with carbon: Part 2. Russian Metallurgy (Metally), 2013 (6), 430-434. doi: https://doi.org/10.1134/s0036029513060165

10. Petryshchev, A., Milko, D., Borysov, V., Tsymbal, B., Hevko, I., Borysova, S., Semenchuk, A. (2019). Studying the physicalchemical transformations at resourcesaving reduction melting of chrome-nickelcontaining metallurgical waste. Eastern-European Journal of Enterprise Technologies, 2 (12 (98)), 59-64. doi: https://doi.org/10.15587/1729-4061.2019.160755

11. Ackerbauer, S., Krendelsberger, N., Weitzer, F., Hiebl, K., Schuster, J. C. (2009). The constitution of the ternary system Fe-Ni-Si. Intermetallics, 17 (6), 414-420. doi: https://doi.org/10.1016/j.intermet.2008.11.016

12. Azimi, G., Shamanian, M. (2010). Effects of silicon content on the microstructure and corrosion behavior of $\mathrm{Fe}-\mathrm{Cr}-\mathrm{C}$ hardfacing alloys. Journal of Alloys and Compounds, 505 (2), 598-603. doi: https://doi.org/10.1016/j.jallcom.2010.06.084

13. Liu, X., Lin, M., Yang, S., Ruan, J., Wang, C. (2014). Experimental Investigation of Phase Equilibria in the Ni-Cr-Si Ternary System. Journal of Phase Equilibria and Diffusion, 35 (3), 334-342. doi: https://doi.org/10.1007/s11669-014-0279-9

14. Jung, W.-G., Back, G.-S., Johra, F. T., Kim, J.-H., Chang, Y.-C., Yoo, S.-J. (2018). Preliminary reduction of chromium ore using Si sludge generated in silicon wafer manufacturing process. Journal of Mining and Metallurgy, Section B: Metallurgy, 54 (1), 29-37. doi: https://doi.org/10.2298/jmmb170520054j

15. Salina, V. A., Zhuchkov, V. I., Zayakin, O. V. (2019). Thermodynamic Simulation of the Manufacture of Fe-Si-Ni-Cr Alloys. Russian Metallurgy (Metally), 2019 (2), 162-164. doi: https://doi.org/10.1134/s003602951902023x 